慶應義塾大学学術情報リポジトリ

Keio Associated Repository of Academic resouces

\begin{tabular}{|c|l|}
\hline Title & Temperature dependence of the pulse-height distributions in aliphatic liquid scintillators \\
\hline Sub Title & \\
\hline Author & $\begin{array}{l}\text { 村瀬, 裕子(Murase, Yuko) } \\
\text { 本間, 義夫(Honma, Yoshio) }\end{array}$ \\
\hline Publisher & 共立薬科大学 \\
\hline Publication year & 1990 \\
\hline Jtitle & $\begin{array}{l}\text { 共立薬科大学研究年報 (The annual report of the Kyoritsu College of } \\
\text { Pharmacy). No.35 (1990.) ,p.50-50 }\end{array}$ \\
\hline JaLC DOI & \\
\hline Abstract & \\
\hline Notes & 抄録 \\
\hline Genre & Technical Report \\
\hline URL & https://koara.lib.keio.ac.jp/xoonips/modules/xoonips/detail.php?koara_id=AN00062898-0000003 \\
\hline
\end{tabular}

慶應義塾大学学術情報リポジトリ(KOARA)に掲載されているコンテンツの著作権は、それぞれの著作者、学会または出版社/発行者に帰属し、その権利は著作権法によって 保護されています。引用にあたっては、著作権法を遵守してご利用ください。

The copyrights of content available on the KeiO Associated Repository of Academic resources (KOARA) belong to the respective authors, academic societies, or publishers/issuers, and these rights are protected by the Japanese Copyright Act. When quoting the content, please follow the Japanese copyright act. 


\title{
Temperature Dependence of the Pulse-Height Distributions in Aliphatic Liquid Scintillators*
}

\author{
Yuko Murase and Yoshio Homma
}

村瀬裕子，本間義夫

The pulse-height distributions for ${ }^{131 \mathrm{~m}} \mathrm{Xe}$ in PPO solutions of aliphatic hydrocarbons such as $n$-pentane, n-hexane, $n$-heptane, 2,4-dimethylpentane, 2,3,4-trimethylpentane, 1-pentene, 1-hexene and 1-heptene are investigated as a function of temperature. The pulse-height distributions are found to be shifted toward higher pulseheight with decreasing temperature. The count rates of ${ }^{131 \mathrm{~m}} \mathrm{Xe}$ remain unchanged with decreasing temperature. The mechanism of the effect is also discussed.

* 本報告はJ. Radioanal. Nucl. Chem. Letters 146(4), 215一222（1990）に発表. 